\title{
Shared parenting, law and policy: considering power within the framework of autopoietic theory
}

Article

Accepted Version

Newnham, A. (2015) Shared parenting, law and policy: considering power within the framework of autopoietic theory. International Journal of Law in Context, 11 (4). pp. 426-443. ISSN 1744-5531 doi:

https://doi.org/10.1017/S1744552315000282 Available at https://centaur.reading.ac.uk/44979/

It is advisable to refer to the publisher's version if you intend to cite from the work. See Guidance on citing.

To link to this article DOI: http://dx.doi.org/10.1017/S1744552315000282

Publisher: Cambridge University Press

All outputs in CentAUR are protected by Intellectual Property Rights law, including copyright law. Copyright and IPR is retained by the creators or other copyright holders. Terms and conditions for use of this material are defined in the End User Agreement.

www.reading.ac.uk/centaur 
Central Archive at the University of Reading

Reading's research outputs online 


\title{
Shared parenting, Law and Policy: Considering Power within the Framework of Autopoietic Theory
}

\author{
Dr Annika Newnham \\ Lecturer \\ University of Reading \\ School of Law \\ Foxhill House, Whiteknights Road \\ Reading RG6 7BA \\ a.newnham@reading.ac.uk
}

Tel: 01183787515

\begin{abstract}
This paper uses the last few decades' developments in the area of shared parenting to explore power within the framework of autopoietic theory. It traces how, prompted by turbulence from the political subsystem, family law has made several unsuccessful attempts to solve the perceived problem of post-separation dual-household parenting. It agrees with Luhmann and Teubner that closed autopoietic systems' developments are limited by their normative and cognitive frameworks, and also argues that changes, which have occurred in family law, show that closed social systems do not function in total isolation. It considers power as ego's ability to limit alter's choices. In our functionally differentiated society, with its recent proliferation of communication, power appears more diffuse and impossible to plot into causal one-way relationships.
\end{abstract}




\title{
Shared parenting, Law and Policy: Considering Power within the Framework of Autopoietic Theory
}

\author{
Dr Annika Newnham \\ Lecturer, University of Reading
}

\section{Introduction}

The topic of shared parenting has, in the last few decades, moved up the political agenda. There have been a number of changes in the law, as the legal system has perceived itself to be under pressure from politics to find a solution to the problems of family breakdown. Yet, autopoietic theory provides an explanation why current reforms are likely to prove no more effective than previous ones. Normative messages generated within one system about the desirability of a particular form of shared parenting are very imperfectly 'translated' (in reality recreated) within a receptor system. Acceptance and rejection depend on the latter's existing normative and cognitive framework: what the system or person can understand and process and what they want to hear.

A carefully crafted and comprehensive new blueprint for the organisation of post-divorce family life was set out in The Children Act 1989 (van Krieken, 2005, p. 33). Since then, the courts have used its orders, notably Parental Responsibility (PR) and Shared Residence Orders (SROs), in ways that had not been envisaged by the Act's draftsmen: away from solely regulating practicalities toward the making of symbolic statements (Harris \& George 2010). As was the case with the 1989 Act, the objective has been to encourage shared parenting after separation. Cautious messages generated within scientific disciplines about the benefits of cooperative parenting have been partially and often erroneously recreated within politics, and 
then within law, to create simplistic exhortations about the need to involve both parents in post-separation parenting. Nevertheless, parents continue to bring these disputes to court and dissatisfaction with the family justice system has persisted; separated fatherhood has come to be understood as a political problem that requires a legal solution (Collier \& Sheldon, 2008).

Although both law and politics are perceived as comparatively powerful, changes to the law have proved ineffective or counterproductive. New reforms have now been introduced in the Children and Families Act 2014. Autopoietc theory explains why this will be a triumph of hope over experience; parents may be unable to understand what the law asks of them or unwilling to adjust because what they are being told is incompatible with what they already understand to be good or bad parenting.

In this context, the question of power becomes interesting. Power can be observed as a process of applying pressure, limiting choices and achieving results. However, this is too simplistic: it can rest with more than one system, can flow in more than one direction, and can be perceived very differently within different systems. In relation to the accommodation of power within the framework of autopoietic theory, this paper is more an invitation to discussion than a presentation of a definitive account.

This article commences with a brief consideration of aspects of autopoietic theory, before looking at power as a generalised communication medium. It then picks up those themes as it details the changes to the law that have been made to encourage shared parenting. It agrees with Luhmann that "[b]eing aware of these fundamental problems of self-observation and self- 
description of the societal system does not lead to resignation; on the contrary, it is a prerequisite to any realistic approach” (Luhmann 1990, p. 101).

\section{Closure in Autopoietic Theory}

There are particular aspects of autopoietic theory that challenge the reader. One is the fact that social systems are made up of communications, rather than people. Law, or the legal subsystem, is not defined as a network of rules or the activities of those who apply and interpret legal rules, but as all communications that use the code legal/illegal to communicate about the law (Luhmann, 1995, p. 286). Communications are the basic units that build the system as they are linked together in circular chains that link past and future communications. Individuals are described as psychic autopoietic systems. Their basic units, a person's thoughts and "the meanings unique to each individual" remain inaccessible to other systems; there is no perfect symmetry between what a person wants to say, and how that is understood and communicated about within social subsystems such as law. (Teubner, Nobles \& Schiff, 2003, p. 917). The system is not only greater than the sum of its parts; it is something altogether different.

Another controversial aspect of autopoietic theory is closure; just as a cell reproduces itself from its own elements and according to its existing blueprint, social subsystems are re-created exclusively by use of their existing communications (Luhmann, 1992, p. 1422). Society is composed of a number of disparate, closed subsystems (and subsystems within subsystems), which have developed as society has become more complex and functionally differentiated. These subsystems are not static, but continually recreate themselves by making new distinctions 
between subsystem and environment and between what is or is not relevant. Legal communications are linked together in two different cycles, which developed consecutively. The first is at the level of operations, communications about what law is doing. The secondorder "hypercycle" consists of communications which observe, evaluate and regulate the subsystem. It insulates law from external pressures, allowing the legal subsystem to self-generate its identity undisturbed (Teubner, 1993, p. 33). Thus, circularity guarantees autonomy (ibid, p. 75). According to Teubner, theorists in jurisprudence had needlessly struggled with the inherent circularity in their accounts of law, erroneously seeing this as a weakness in their theoretical model rather than an inescapable feature of law (ibid, p .9). Only the law decides what it lawful, and it does this only by referring to its own, previous communications (Teubner, Nobles \& Schiff, 2003, p. 905). There is no privileged position of observation, metanarrative or Grundnorm (Luhmann, 1992, p. 1428).

The assertion that law is closed off from other systems appears to be contradicted by observation. Legislation requires law to import a variety of political, economic or social values, while law's role as arbiter of disputes requires it to acknowledge external information and communicate its normative pronouncements to the outside world (Smith, 2004, p. 334). However, what looks superficially like law importing terminology from politics, economics or elsewhere, is in fact one subsystem using the meaning-making materials of another "to reformulate something new in its own internal context" (Teubner, Nobles \& Schiff, 2003, p. 916). This has been termed re-entry. Rather than law actually admitting new material from the environment into itself, legal communications create an internal version of the environment, misunderstood according to law's preconceptions and limitations. Law has its own idea of what politics or economics are about, but no direct access to those subsystems, and vice versa. 
Law does not actually solve problems in its environment (or, if you like, in the real world); it is only within its internally reconstructed version of reality (created through the process of reentry) that problems appear to be solved.

Where an event, such as the passing of an Act of Parliament, is communicated about in two or more subsystems, this can create an illusion of compatibility. However, even where the same words are used, their meanings differ between subsystems, as do the criteria used to judge success or failure. The communications about the event are "not only analytically but empirically distinct from each other" (Teubner, 1998, p. 27). This is termed structural coupling (Teubner, 1998, p. 27). Similarly the making of an order in a contact/residence dispute will take on different meanings for the legal subsystem and the individual litigants. Structural coupling does not allow a straightforward transfer of information, but it can create turbulence which forces subsystems to adjust, particularly if turbulence is perceived to be coming from a more powerful subsystem.

As mentioned in the introduction, closed subsystems are built around obfuscated tautologies or paradoxes. Law determines what is lawful based on criteria it has designed: "it is legal, because it is legal" is the tautologous paradox at the heart of law (Teubner, Nobles \& Schiff, 2003, p. 919). Modern law, which has become highly politicised due to "intense structural coupling" with politics and economics, is vulnerable to demands for some "fundamental fact or value" to underpin the legal/illegal distinctions (ibid, p. 909, p. 919). However, as Luhmann has observed, such a value cannot be provided: "[t]here are paradoxes everywhere, wherever we look for foundations" (Luhmann, 1988, p. 154). They cannot be eliminated, only hidden in order to be ignored (ibid, p. 161). 
One way for subsystems to obfuscate tautologies and paradoxes is through the making of further distinctions, e.g. between the creation of new law through (political) legislation and the (neutral) administration of justice. Thus, the structural coupling that occurs when new legislation is enacted is usefully employed by both the legal and political subsystems to explain away the paradoxes at the heart of the subsystems (Luhmann, 1988, p. 160).

Closed subsystems, which evaluate themselves through second-order cycles of self-evaluation, develop their own understandings of what they are, and of what role they fulfil in society. ${ }^{1}$ Luhmann has observed that whereas self-descriptions based on paradoxical approaches (the system should be what it isn't) make for progressive, "if not revolutionary" self-descriptions (and systems), descriptions based on the tautological (the system is what it is) result in systems which understand themselves to be rather conservative (Luhmann 1990, p. 127). This is the case of law. It explains law's continued loyalty to traditional, gendered understandings of family. Furthermore, "[i]f society is supposed to be what it is, then the solution can only be to conserve society, to continue to solve its problems, and possibly to improve problem solving and to overcome unexpected difficulties" (Luhmann 1990, pp. 127-128). This is a very apt description of how family law has dealt with the problem of demographic change and postseparation parenting (but not how this 'problem' has been understood elsewhere, for instance by parents).

\section{Power}

On the basis of their own understandings of their environment as generated through re-entry. 
In his 1979 book Power, Luhmann saw power particularly in terms of limiting choices. Whilst power is rooted in the physical reality of force, social systems are not concerned with actual power, only with their own internal understandings of power. It therefore makes more sense, it is submitted, to discuss perceptions of power, and how messages about these are included in communications. This is, indeed, largely the focus of Power. ${ }^{2}$ This paper, too, is predominantly concerned with perceptions of power. Since systems are closed and cannot really directly force changes in their environments, what matters is less what systems can actually achieve than what is considered possible through communications involving power. That said, since the paper is concerned with interactions between systems, there are some observations on power per se, albeit as perceived and discussed within autopoietic theory.

Luhmann, drawing on Parsons, categorised power as a "symbolically generalized communication medium" (1979, p. 108). These media (other examples include money, truth and love) are "mechanism[s] additional to language" (ibid, p. 111) which facilitate communications by reducing both contingency and complexity. In modern, functionally differentiated societies, abstract power codes have developed which bring speed, efficiency, predictability. A communication is accompanied by a "meta-communication" about power (Luhmann 1979, p. 124). Alter can be expected, to a greater extent, to accept ego's recommended solutions (ibid, p. 116). Its relatively abstract nature makes it easier for power to 'travel' across system boundaries in the sense that perceptions of power can be recreated with comparative ease within a second system on the basis of its observations of the first system (ibid, p. 171).

\footnotetext{
However, a problem with relying solely on Luhmann's account of power in Power when exploring the role of power in autopoietic systems is that this comparatively early book makes frequent references to power holders as individual participants; although society as a system is mentioned it is not clear that society is not designed and driven by people but a system of communications.
} 
Law's role is to impose order and it resists challenges which are likely to cause further conflicts (Luhmann, 1989, p. 144). Complex and diverse disputes are reduced to generalisations or repetitions, which mask tensions and create an impression of internal consistency (Teubner, 1993, p. 57). A legal norm cannot be allowed to lose its validity "just because someone infringes it" (Luhmann, 1995, p. 296). A speed limit, for example, is not increased because many motorists exceed it. Law is cognitively open (it 'admits' or recreates information) but normatively closed (new information does not generally cause law to adjust its standards). Law is what it is. This counterfactual stability creates an impression that law is powerful, since it can choose to refuse to adjust. It can be argued that to some extent law becomes powerful if it is perceived to be powerful, since others will more readily limit their choices in response to legal communications.

Luhmann acknowledged the difficulties inherent in explaining power in a way that is both theoretically and empirically satisfactory $(1979$, p. 107). His account of power answers some questions, but raises others. If power is not exclusively force (and that is too simplistic a description for a complex society) then what is it? Should it be defined in the narrow sense of political power, or the widest sense as anything alter can use to influence ego's selections: we could say that alter has power over ego? However, both these definitions seem inconsistent with Luhmann's discussions in Power; it is made clear that power can be both illegal and informal (ibid, p. 134) and that other symbolically generalized communication media, for example love, can also be used to influence choices (ibid, p. 175). What is clear, and helpful, is that power is not force or coercion (zwang): it decreases, rather than increases, when threats have to be 
carried out (ibid, p. 121). Nor is it a zero-sum game: power in a society increases as complexity increases and there are more contingencies to regulate (ibid, p. 146).

It is important to recognise, however, that whilst power limits choices, it cannot guarantee outcomes (Luhmann 1979, p. 114). As is often stressed within autopoietic theory, there is no simplistic relationship between cause and effect. Power can be multidimensional and multidirectional, and it also includes the power to thwart or avoid decisions (ibid, p. 163). These observations are confirmed by a closer examination of the relationships between politics, law, and particularly individual litigant parents.

The aim of this paper is not to provide a comprehensive taxonomy, and may raise more questions than it answers, thus stimulating further discussion. It must be acknowledged that there is no privileged, neutral vantage point outside of systems that can be used to ascertain the actual operation of power. All that can be offered are observations from one perspective; most of these are concerned with perceptions of power, but some discuss how power can be seen and described within autopoietic theory.

\section{Family Law: The Children Act 1989}

If law generally appears powerful because it can refuse to adjust in the face of disappointed expectations, then a clear exception is law's relationship with politics; law has to respond to and implement new legislation. Luhmann has observed that the political system, as part of its environment, has a particular impact on the legal system (Luhmann 1990, p. 229). The paradox that only law can say what is lawful is hidden by references to the political system; a 
crucial part of the system's strategy to portray its self-determinations as "natural, necessary, and lacking functional alternatives." (Luhmann 1990, p. 139). Furthermore, in family law as in other areas, an increasing amount of new law now comes in the form of legislation as politics presents law with new problems to solve (Luhmann 1990, p. 235). In this sense, politics seems more powerful than law, since in the face of turbulence from the former, the latter cannot choose to do nothing. Political power, according to Luhmann, does not have to be "created anew" within law, it is enough "that it exists somewhere and can be called upon" (1979, p. 171).

The Children Act 1989 illustrates, however, that what politics seeks to communicate to law will not be straightforwardly recreated within the legal subsystem since the process depends on law's existing normative framework. Power is not enough; while politics limits law's choices due the latter's perception of the former as more powerful, a number of other factors are also involved: law's reading of the situation as coloured by its internal normative framework, law's resistance to change where it is perceived to be too costly or where it seems incompatible with current aims, and law's reliance on its own cognitive framework to understand what is being said. In this way, power is limited: alter can influence, but never straightforwardly dictate, ego's choices.

The legal subsystem's understanding of the 1989 Act was determined by how it 'saw' the world, just as individuals' conceptions of reality are coloured by their earlier experiences. The draftsmen behind the Act sought only to help parents make arrangements to share the care of their children in ways that suited them, and were not concerned with gender relations or social change. This was not, however, how the Act's regulatory framework came to be understood 
within law. Feminist scholars have long criticised family law for its preoccupation with perpetuating hierarchical nuclear family structures (Rifkin 1980, p. 83; DuBois et al 1985, p. 13). To assert this is not incompatible with autopoietic theory since a patriarchal framework of reference was part of law's normative make-up when it initially closed itself off from society through functional differentiation. Law, like autopoietic systems in general, demands binaries: legal/not legal, public/private, male/female, and the private or female has been left unregulated and invisible without this being viewed as problematic since this patriarchal view has become habitual, a part of the subsystem's identity. This has traditionally turned attention away from caring and other activities that occur within the supposedly private sphere. Mothering has been largely ignored, implicitly understood as a selfless, natural outpouring of love that can be taken for granted (Lawler, 1999, p. 67).

Commentators around the time of the enactment of the Children Act 1989 observed that the increased prevalence of divorce, single parenthood and unmarried cohabitation had exposed the fragility of the nuclear family paradigm (Roche, 1991, p. 349). This was presented in political communications as a problem law ought to address (Murray, 1996). In response, law sought to contain the anxieties surrounding this demographic change by reconstructing parenthood to replace marriage as the primary relationship with the "reassuring irrevocable permanence", which can endure "unaffected by the vicissitudes of adult life" and thus have a stabilising influence on individuals, families and society (Roche, 1991, p. 349). Reasons why this did not work will be examined below.

\section{Law and Child Welfare Experts}


External information does not only affect family law through legislation. Although law is normatively closed, it "can and must" be cognitively open "where fact-finding is concerned" (Luhmann, 1995, p. 296). Disputes between parents about who should care for their children are decided according to the welfare principle, contained in s1(1) of the Children Act 1989, which has been interpreted in case law as stipulating that the child's welfare must be the court's first and only consideration. ${ }^{3}$ A welfare checklist of factors to consider is contained in s1(3), but it is non-exhaustive and non-hierarchical and not intended to fetter judicial discretion. Choosing the 'best' solution means law is forced to abandon its usual retrospective approach and attempt to predict the future. Thus, decisions must, to a large extent, be based on external expertise on what harms or helps children (Smith, 2004, p. 319). However, "the reliability of any area of knowledge is always open to the court's critical scrutiny, and what any expert is actually expert in is a matter for the court to decide". (van Krieken, 2006, p. 576). Furthermore, information has to be presented in legal code. As Lord Hoffman explained in Re $B$, law needs to convert possibilities into certainties; "there is no room for a finding that [something] might have happened". ${ }^{4}$ Ryder LJ is quite correct to have commented, extrajudicially, that this approach to findings of fact is "legal fiction" (Ryder, 2008, p. 30). Indeed, Lord Hoffman's observations fit well with Teubner's assertion that regardless of pressure from external sources or even internal aspirations, law can only recreate knowledge using its own cognitive framework and its own language (2001, p. 24).

King and Piper have examined family law from an autopoietic perspective, confirming that what superficially appears to be the wholesale importation of information is, instead, a

\footnotetext{
$3 \quad J v$ C [1970] AC 668. This could be thought to conflict with a human rights approach which requires consideration of all parties' rights and interests, but the paramountcy principle's compatibility has been confirmed both by domestic courts, e.g. in Re B (A Minor) [2001] UKHL 70 and by the European Court of Human Rights in Yousef $v$ Netherlands [2003] 1 FLR.

$4 \quad$ Re B [2008] UKHL 35 per Lord Hoffman at [2].
} 
recreation of modified versions of that knowledge within law (1995). They assert that a separate autopoietic subsystem has developed, which they label child welfare science. Initially an amalgam of predictions from medicine, psychology, psychiatry and social work about what is good for children, it has developed its own discursive identity, with its own meaning-making procedures and personnel, and with a binary code of "bad for children" or "good for children" (King \& Piper, 1995, p. 43). As Rejmer has noted, this system, too, appears increasingly selfreferential and self-reinforcing (2003, pp. 83-84). It is, however, a system that perceives itself to be less powerful than law, possibly because it prioritises cognitive openness, while law's stress on normative closure means it is typically described as "unyielding, internally cumbersome and resistant to change" (Philippopoulos-Mihalopoulos, 2003, p. 5).

The participants in this new discourse are well-versed in structuring their communications to suit the legal subsystem. Researchers using autopoietic theory found that when social workers were presenting children's wishes and feelings to the courts, the latters' views were reinterpreted through the dual filters of child welfare science and family law, into a "legalistic code" which was thought easier for courts to use (James et al, 2004, p. 193; Rejmer, 2003, p. 188).

This reinterpretation to suit law (at the expense of the powerless children who are supposed to be the courts' paramount concern) is a good example of how individuals can participate within several subsystems, modifying their communications accordingly, but are "severely constrained"; if they choose to communicate, and want to do so successfully, they must do so on the terms dictated by the subsystem (Schiff \& Nobles, 2009, p. 30). All communications must take for granted a level of prior shared understanding, which sets the parameters for what 
can be communicated (Luhmann 1979, p. 142). If social workers giving evidence wish to have their communications accepted within law they must, like lawyers and judges, speak and write as if they broadly agree with existing legal standards (for example on what is good for children), and in a way likely to be understood by law (Schiff \& Nobles, 2009, p. 33). It is submitted here that if law is perceived to be comparatively powerful within other social subsystems, and by individual psychic systems, choices will be made to speak law's language as a means to an end, and law's comparatively unchanging nature will reinforce the perception of it as powerful. ${ }^{5}$

Conseqeuntly, law has enslaved child welfare science information to create "a selective and simplified version of welfare" (Kaganas \& Piper, 2002, p. 377). This has, further, been coloured by law's blindness to the private, domestic or feminine, and its inability to value mothering. Thus, psychiatry's "fluid predictions", for example, have become “oversimplifications" (Clarkson \& Clarkson, 2007, p. 267). “Law’s operations are smoother”, according to Philippopoulos-Mihalopoulos, "when noise has been previously masticated into potential order" (2003, p. 25). Law's preference for the abstract and generalised has moved family law from the observation that a good relationship with a father is very important to some children to the assertion that all children need relationships with their fathers. ${ }^{6}$

The 1990s de facto presumption in favour of contact meant that risks of harm associated with addiction, psychiatric illness, domestic violence and even allegations of child abuse were incorrectly held to be outweighed by the supposed natural benefits of contact with the child's

Parents, too, are likely to see law as powerful, due to its close association with political power and its enforcement messages. Nevertheless, as will be explored below, this does not guarantee results.

$6 \quad$ See e.g. Adam J quoted by Sir Mark Potter P in Re A [2008] EWCA Civ 867 at [35]. Mothering, however, remains invisible to law and largely taken for granted. There is, therefore, no perceived need to support or encourage it in these cases. 
father; ${ }^{7}$ this judicial optimism also meant courts failed to address the problems posed by inexperienced, incompetent or untrustworthy applicants. (Barnett, 2009, p. 139). The fact that the pendulum had swung too far in favour of contact was eventually acknowledged by the Court of Appeal in Re L, V, M, H [2000]. ${ }^{8}$

Yet, as acknowledged by Thorpe LJ in that case, a general "assumption" in favour of contact remains.9 In Re P [2008] Ward LJ remarked that there could be "no doubt of the secure foundation for the assumption that contact benefits children”. ${ }^{10}$ As Gilmore has convincingly demonstrated, no such firm foundation can be found in the child welfare sciences (Gilmore, 2008, p. 1227). Law, however, sees itself as sufficiently powerful to ignore this; it decides how to resolve contact cases, and chooses to do so by referring predominantly to its own internal communications.

However, the new legal framework of the 1989 Act and the judicial pro-contact stance entrenched through comments in a number of judgments failed to 'solve' the problems of separated parenthood and dissatisfied fathers. ${ }^{11}$ Imperfectly translated normative expectations that are imperfectly communicated from politics to law to individual parents could not be expected to 'fix' the problem of these disputes.

In the Children Act 1989, custody and access had been replaced with parental responsibility (PR), residence and contact to "lower the stakes" and avoid creating winners and losers (Law

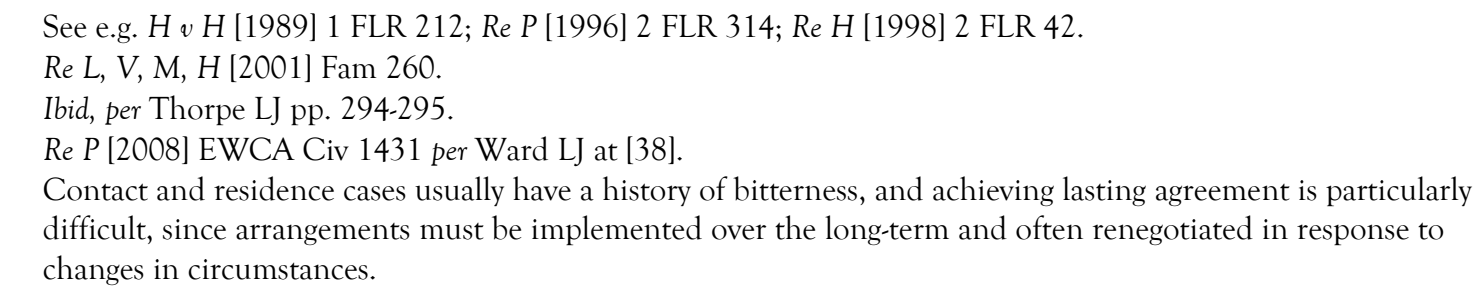


Commission, 1986, para 7.18). ${ }^{12}$ Residence was to answer the practical question of where the child was to live, while PR was introduced in s3(1) to deal with "all the rights, duties, powers, responsibilities and authority which by law a parent of a child has... ${ }^{13}$ This was designed to allow the non-resident parent to retain equal status with the primary carer and provide an incentive for continued involvement with the child (Law Commission, 1988, para 4.5). Court statistics and media coverage for the twenty years after the Act's implementation showed, however, that increasing numbers of parents were turning to court, and that contact disputes, in particular, remained a controversial topic. ${ }^{14}$ Fathers' groups complained that contact orders were not enforced sufficiently robustly, and that PR, designed to mirror practical involvement, was now given to almost all fathers but had consequently become little more than a symbolic signifier of the formal status of fatherhood (Reece, 2009; Harris \& George 2010).

Observing the dynamic between the individual fathers who make up these groups and the political and legal subsystems leads to the suggestion that power relationships, like the chains of communications within closed subsystems, are circular in nature. As Luhmann observed, there are flows and counterflows of power (Luhmann 1979, p. 163). Communications by fathers' groups created turbulence that was heard by politics and resulted in communications

12 Law Commission (1986) Family Law Review of Child Law: Custody, Working Paper No 96, London, HMSO, [7.18]; Department of Health (1991) The Children Act 1989: Guidance and Regulations, Vol 1, Court Orders, London, HMSO, [2.25].

13 Under Sections 2 and 4 of the Children Act 1989, PR is acquired by mothers, married fathers, and all fathers who register the birth of the child. It signals that parenting roles continue post separation. PR can only be lost by adoption or by unmarried fathers; the latter has only happened once in five years in Re D (A Child) [2014] EWCA Civ 315.

14 For court statistics on the steady increase in these cases, see e.g. Judicial and Court Statistics 2006, p. 85, available at https://www.gov.uk/government/uploads/system/uploads/attachment_data/file/243134/7273.pdf and Judicial and Court Statistics 2011, p21, available at https://www.gov.uk/government/uploads/system/uploads/attachment_data/file/217494/judicial-court-stats2011.pdf last accessed $18^{\text {th }}$ September 2014. For media coverage see e.g. Ross, T (2012, July 25) Father's rights breached by mother 'too upset' to let him see children, The Telegraph, available at http://www.telegraph.co.uk/news/uknews/law-and-order/9424060/Fathers-rights-breached-by-mother-too-upset-tolet-him-see-children.html last accessed $18^{\text {th }}$ September 2014. 
within the latter subsystem. ${ }^{15}$ Particularly successful was the publicity-seeking group Fathers4Justice, led by former Marketing Consultant Matt O'Connor. He has been quoted as saying: "...if you can catapult stuff into the headlines, good or bad, then you've created something that gets ingrained in the public consciousness as a brand" ${ }^{16}$ Politicians' concerns that this view of family law as 'failing' was increasingly shared by voters (perceived as collectively powerful as they select governments), led to further pressure on law to solve the supposed problems of biased, secretive or inefficient courts that fail to enforce contact and secure men's ties to (and control over) their children within new binuclear post-separation families (Collier \& Sheldon, 2008; Kaganas, 2013). Politics sees itself as able to influence voters' choices, but simultaneously has to acknowledge that power does rest with the latter, too. Thus, different systems can be perceived to have different kinds of power at the same time; power is multidimensional. It does not rest in only one place, nor can it be mapped into fixed hierarchies, but it is to a large extent situational.

As a result of this turbulence from politics, family law enslaved another discourse, that of mediation, and the legal understanding of the SRO changed away from the regulation of practicalities towards the sending of symbolic messages.

\section{Law's Enslavement of Mediation Discourse}

15 There are other stakeholders, notably those representing mothers and children, who have criticised the system for the opposite reasons; that courts are far too ready to order contact with violent and dangerous men. However, these communications have not had the same success in terms of being heard. This is perhaps because law observes its environment through an inherent, patriarchal lens, and because concerns raised on behalf of these groups do not resonate as well with political anxieties about fatherlessness, delinquency and loss of societal cohesion. See Smart (1995).

16 D, Ross, "Matt O'Connor, the Man behind Fathers4Justice", The Independent, $4^{\text {th }}$ July 2006. Available at http://www.independent.co.uk/news/people/profiles/matt-oconnor-the-man-behind-fathers4justice-406610.html last accessed $1^{\text {st }}$ February 2014. 
In 1995, King and Piper, writing from an autopoietic perspective, were understandably pessimistic about family law's capacity for fundamental change (p. 29). They contrasted the traditional legal retrospective and adversarial approach with the "welfarist" approach as typified by mediation, where compromise is encouraged by drawing attention away from allegations of past wrongdoings and constructing a narrative where both parents have the will and capacity to be responsible and sensible (ibid, p. 91, p. 94). Anyone interested in family law reading these comments would be struck by the changes that have, indeed, occurred since this was written: the latter description is now more accurate for family law.

These changes confirm the assertion that, although change within an autopoietic system is slow and largely unplottable, it does occur. At times, changes of self-description become necessary. As Luhmann has asserted, self-descriptions have important systemic functions; but if they become too costly in terms of the apparent lack of fit between tradition and reality, they must be jettisoned (1990, pp. 123-124). The traditional legal approach could not solve most contact disputes; parents were not only coming to court, but were also returning to court again (and again) when orders were breached, while fathers' groups' protests created an impression of widespread dissatisfaction with the family justice system. A different approach was needed to create the impression that these conflicts were being solved and that families in flux were being stabilised into new binuclear families. Thus, the terminology used by mediators and child psychologists has replaced the adversarial legal language of blame and fault (James, 2003, p. 137). There has been a significant shift in normative expectations. Litigating spouses/parents are encouraged to reach their own agreements by their lawyers, by the Children and Family Court Advisory and Support Service (Cafcass) at in-court conciliation, and by judges who order mediation or Separated Parents Information Programmes (Smith \& Trinder, 2012). 
This does not, however, contradict the statement that there can be no "shared normativity" (Teubner, 1993, p. 65); what has been incorporated is the legal system's own version of mediation-within-law (King \& Piper, 1995, p. 59). As mediation has been accommodated into the legal framework, the focus has been narrowed to agreement on the immediate issues rather than long term resolution of conflicts. Mediation is often considered to be working well; but success is assessed solely in terms of quantity rather than the quality of the agreements reached (Ryrstedt, 2009, p. 821; Rejmer, 2003, p. 118). Mediation has been subordinated to, or fitted into, law, rather than the opposite occurring. According to Teubner, the closure of autopoietic systems does not render the issue of power irrelevant (1993, p. 79). The extent to which one social subsystem can enslave another depends on subsystems' internal perceptions of other systems' relative power and authority (ibid, p. 103). In the English courts, the focus has narrowed to agreement on the immediate issue of contact rather than the quality of agreements and the long term resolution of conflicts (Smith \& Trinder, 2012, p. 432). Although the same terminology is used, words have slightly different meanings, and the objectives adjusted to suit law's purposes.

Law's focus on how things should be rather than how they are means that mediation's ideal has become law's new standard. Already by the late 1990s, researchers looking at legal communications found a binary divide between the 'good', forward-looking conciliatory divorce and the 'bad' adversarial one, noting that these classifications were "becom[ing] entrenched through the cumulative effect of self-reinforcing professional received wisdom" (Bailey-Harris et al, 1999, p. 122). Thus, if a responsible parent always puts the child first, recognising the child's paramount need to know the other parent, and conflict per se is 
constructed as harmful, then parents who resist contact are prima facie in the wrong, irresponsible and unreasonable. "Compromise", according to Wall LJ, "is an art that every separated parent ought to master". ${ }^{17}$ Since law sees itself as a system that is to be obeyed (and thus a comparatively powerful system), judicial 'lectures' to parents regarding the harmful effects of conflict are becoming commonplace. ${ }^{18}$ In Re R [2009], Wall LJ read the first four lines of Philip Larkin's poem This be the Verse and cautioned the parents that unless they could protect their son from their fighting they might well lose him. ${ }^{19}$ This is a threat oft-repeated by judges but rarely carried out. Its effectiveness lies in persuading mothers to allow fathers access to their children. As Luhmann asserted, power is diminished, not increased, with the actual use of coercive threats. "Part of the communication of power", according to Luhmann, "is that the power-possessor would rather not realize his avoidance alternative but is prepared to do so" (1979, p. 139).

A final point in relation to law's enslavement of mediation is that law's expectations remain gendered, mothering continues to be constructed as natural and self-sacrificing, and therefore invisible because it can be taken for granted. It is primarily mothers who are to be persuaded of the need to collaborate with fathers, not vice versa (Kaganas, 2013, p. 281). Mediation's understandings of the 'good' post-separation family have been recreated within law subject to the latter's pre-existing patriarchal understanding of families. The law's lack of interest in mothering, and in encouraging mothers, can make them seem powerless. However, different systems can take contradictory positions on the allocations of power. The fathers' rights movement would assert the contrary: that mothers are too powerful. As will be explored in

\footnotetext{
Re G [2008] EWCA Civ 1468 at [7].

See e.g. Re J [2004] EWCA Civ 1188 per Wall LJ at [5-6]; Re T [2009] EWCA Civ 20 per Wall LJ at [66]. Re R [2009] EWCA Civ 358 at [124], [128].
} 
Section 9, political communications from government suggest that this view of mothers as selfish wielders of power has influenced recent law reform. These differing perceptions of who is powerful add another level of complexity to any attempt to define power.

\section{The changing Shared Residence Case law}

When parents are expected to reach their own agreements, the attraction of a shared residence order (SRO) is its superficial fairness: if you divide children's time in half then both parents are equal, and they have nothing left to fight over. ${ }^{20}$ At the same time, this solution is compatible with the new paradigm of the binuclear family.

There is no firm definition of shared residence. The Children Act 1989 states in s11(4) that a residence order "may specify the periods during which the child is to live in the different households concerned" but there is no stipulation as to time. The distinction between shared residence and sole residence with generous overnight contact is essentially a question of degree. $^{21}$

Initially, courts adhered to the original Children Act understanding of shared residence. Residence orders were, "as their words indicate, practical orders". ${ }^{22}$ However, an alternative line of cases developed where shared residences orders were made, it seemed, primarily to ease former primary carers' sense of loss, and thus avoid a deterioration of relationships. ${ }^{23}$

This type of argument was aired inter alia in Av A [2004] EWHC 142. At the same time, this solution is compatible with the new paradigm of the binuclear family.

Re K [2008] EWCA Civ 526

Re H [1995] 2 FLR 883 per Ward LJ at p. 889.

Re N, unreported, Court of Appeal, 2nd September 1994; Re R [1995] 2 FLR 612. 
Nevertheless, applications were generally refused in cases where parents were unable to communicate or co-parent effectively. ${ }^{24}$

However, a reversal of this causal relationship between parental cooperation and the SRO began in $D v D$ [2001]. ${ }^{25}$ This case is regarded as having significantly changed the law by removing any "gloss" from the welfare principle that made this order more difficult to obtain. ${ }^{26}$ $D v D$ was decided on the basis of a near-equal division of the children's time, ${ }^{27}$ but recognition of the children's reality was only one of two stated objectives. The second was for the parents to use this framework, and its symbolic connotations of equal status, ${ }^{28}$ to "go away and make contact work" ${ }^{29}$ Subsequent cases continued to emphasise that a SRO must reflect practical realities, but, once this was established, judges were increasingly swayed by arguments about symbolic messages. ${ }^{30}$ In the high-conflict A v A [2004] the order was explicitly made to reduce animosity between the parents. ${ }^{31}$ The case has subsequently been cited as authority for the fact that shared residence was appropriate even in cases where parents were unable to talk to each other. $^{32}$ Again, family law was being used to mask unsettling societal change by creating the appearance of the traditional nuclear family, headed by a father, continuing in a binuclear form across two households.

Co-parenting, within the SRO framework, has been given a new, narrow legal meaning. It is defined in negative, rather than positive, terms: one parent must not interfere with the other's

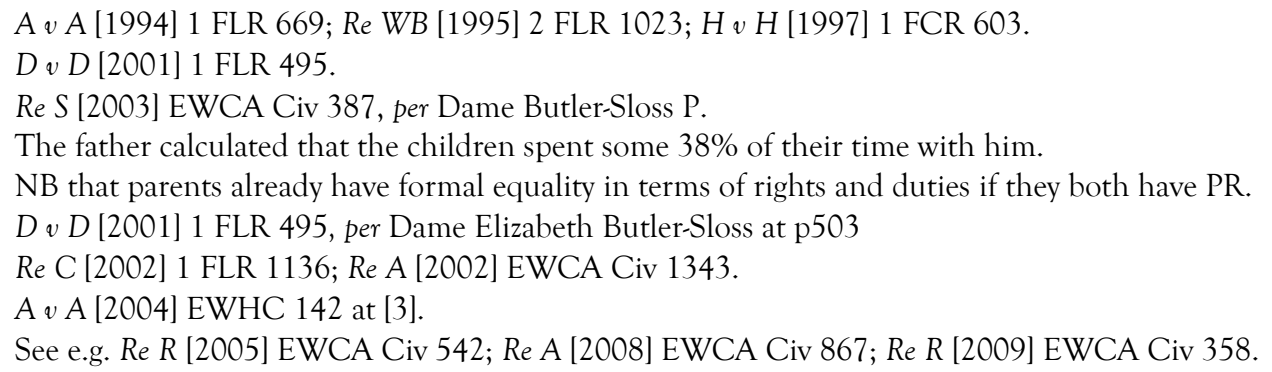


exercise of PR in relation to day-to-day matters. ${ }^{33}$ This has ensured that the SRO, now perceived to be the solution to the problem of high-conflict families, could be available to greater numbers. The law, according to Luhmann, "cannot allow a legal norm to lose its validity just because someone infringes it" (Luhmann, 1995, p. 296). If parents have to learn to cooperate within these new dual-household post-separation families, then they should. Law continued to seek to influence parents' choices even in the face of their opposition; this suggests that the legal subsystem views itself as quite powerful (whether it actually is or not).

At this stage, using the SRO to teach parents to cooperate was still seen as an added benefit to the requirement that the order must, as the draftsmen behind the Children Act had insisted, reflect practical realities. By 2008, however, commentators observed that shared residence had developed "a special meaning" that was "far removed from the statute" (Spencer, 2008, p. 24). Moreover, it had departed from the child welfare science understanding of when the SRO could be 'good' or 'bad' for children. Gilmore rightly expressed concern over the judicial tendency to refer only to other judgments and without engaging with research knowledge on how parental conflict is known to affect children (Gilmore, 2006, p. 497). A number of studies show that "conflict between parents that is frequent, intense and poorly resolved is particularly damaging" (Smith \& Trinder, 2012, p. 431).

Law, as subsystem, may be cognitively open, but it alone determines what will be considered. In Re A [2008] and Re R [2009] judges expressly declined to follow psychiatrists' recommendations against shared residence, preferring instead to rely on the new, legal

\footnotetext{
33 A v A [2004] EWHC 142 per Wall LJ at [118]; Douglas, G (2006) "Residence: Re P (Shared Residence Order)" Family Law, 447.
} 
definition from case authorities. ${ }^{34}$ This fits well with Luhmann's claim that law asserts its power by deciding what it regards as relevant or irrelevant purely by reference to its internal criteria $(1989$, p. 141).

As communications in judgments were linked to previous communications, this new understanding of the SRO was strengthened. While the original understanding of the SRO was occasionally re-asserted in judgments, ${ }^{35}$ these communications tended not to be repeated by other judges, and not to become part of the changing case law.

In Re T [2009] Wall LJ described equal division as "rare", suggesting that most cases now departed from what had previously been presumed to be the standard shared residence arrangement of 50/50 sharing. ${ }^{36}$ In Re W [2009] Wilson LJ quoted Sir Mark Potter P in Re A [2008]: "It is now recognised by the court that a shared residence order may be regarded as appropriate where it provides legal confirmation of the factual reality of a child's life or where, in a case where one party has the primary care of a child, it may be psychologically beneficial to the parents in emphasising the equality of their position and responsibilities." ${ }^{37}$ The two purposes identified in $D v D$ [2001] have been separated; in the quote they are linked with "or", rather than "and". Elucidating further, Wilson LJ identified recalcitrant primary carers (usually mothers) as the target group for this new use of the SRO. ${ }^{38}$ In other cases, SROs were

\footnotetext{
34 In Re R [2009] EWCA Civ 358 Wall LJ stated at [30] that the SRO under s.8 "is a legal, not a psychiatric concept"; Re A [2008] EWCA Civ 867 per Adam J at [58].

35 Ward LJ, who continued to insist this was an essentially practical order, was prompted to observe in Re G [2008] EWCA Civ 1468 at para 17: "A residence order gives the mother no added right over and above the father. That is the lesson that has not yet been fully learned in the 19 years that the Act has been on the statute book".

36 Re T [2009] EWCA Civ 20 at [35].

37 Re W [2009] EWCA Civ 370 at [11].

38 Re W [2009] EWCA Civ 370 at [15].
} 
made despite decidedly unequal allocations of time and considerable geographical distances between the parents. ${ }^{39}$

As Collier and Sheldon have argued, family law's current focus on ensuring fathers' continued attachment to their children through a dual-household family must be linked to "wider policy agendas". (Collier \& Sheldon, 2008, p. 218) Modern fatherhood is constructed within both the political and legal subsystems as a "problem" to be "managed" by law" (ibid, p. 176). This view has been strengthened as fathers' rights organisations continue to express their frustration at family law's perceived bias and toothlessness, and individual fathers demand shared residence as the only way to obtain equal status (Spencer, 2008, p. 24). Furthermore, law's conservative normative framework and view of itself as existing to stabilise society also made it comparatively easy for it to internally reconstruct campaigners' doom-mongering linking of fatherlessness, delinquency, and social disintegration (see e.g. Geldof, 2003, p. 182). As a result of these perceived pressures, the predominantly or exclusively symbolic use of the order came to be accepted as commonplace by judges and others involved in the family courts. ${ }^{40}$ In Re A R, Mostyn J, said the SRO "is nowadays the rule rather than the exception even where the quantum of care undertaken by each parent is decidedly unequal". ${ }^{41}$

\section{Why Parents Reject Family Law's Normative Pronouncements}

\footnotetext{
39 D v S [2008] EWHC 363; CC v PC [2006] EWHC 1794; Re N [2006] EWCA Civ 872

40 For example, in Re A [2008], an application by a step-father, the Cafcass reporter observed: "Had Mr A been H's biological father, it would have been reasonable for the Court to order shared residence, as a reflection of the equal status and the responsibilities of the mother and Mr A". Re A [2008] EWCA Civ 867 at [49].

41 Re A R (Children) [2010] EWHC 1346 at para.52.
} 
However, the combination of the strong pro-contact stance, the use of PR to encourage paternal involvement and the redefinition of the SRO as a panacea for high conflict families failed to 'solve' the problems of separated parenthood. Dissatisfaction with family law has remained. From an autopoietic perspective, it is well known that changes sought by one system are rarely straightforwardly achieved in the other. The second system will not respond as required, as it "obeys a different internal logic" (Teubner, 1998, p. 22). Power includes the power to obstruct (Luhmann, 1979, p. 163). These statements apply not only to the interference between the legal and political subsystems, but also to law's attempts to modify the behaviour of separated parents.

Research shows that just as it is only rational within the financial subsystem to obey the law if this results in a profit, parents in contact and residence cases perform similar cost/benefit analyses. They feel justified in disobeying legal pronouncements where these conflict with their internal moral codes (Laing, 2006; Kaganas, \& Day Sclater, 2004). When interviewed, mothers linked resistance to contact to their duty to protect their children from the risks posed by dangerous, incompetent or unreliable fathers, while non-resident fathers saw continuing, stressful court battles for contact as the only way to prove their love for their children. The other parent was always blamed for litigation. It is too costly for parents to abandon selfdescriptions that classify them as good and committed parents; instead the new information from law is recreated so as to suggest that these parents are legitimate exceptions to the general rules (Laing, 2006; Kaganas, \& Day Sclater, 2004). Thus, they see the comparatively powerful legal system as directing and limiting, but not dictating, their choices. 
Furthermore, law, as a subsystem, does not 'see' the individuals who appear before it, but instead its own, internally recreated versions (Teubner et al, 2003, p. 915), a set of simplified semantic artefacts including the vulnerable child, the supportive or implacably hostile mother and the sincere or dangerous father who are described in case reports. Research has found a gap between family law's abstract norms based on ordinary, responsible parents, and the real cases where the families were more often than not struggling with unemployment, poverty, addiction, physical or mental ill health. Often the right questions were never asked. For the adults and children, this resulted in wasted efforts, repeated disappointments, and a sense of powerlessness (Rejmer, 2003, pp. 73-76; Ekbom \& Landberg, 2007, pp. 34-35).

In England and Wales, Smith and Trinder evaluated the latest initiative designed for embittered parents: the Separated Parents' Information Programme (PIP). They drew on autopoietic theory to observe that, ironically, PIP is promoted as an alternative to ineffective courts, yet it fails to achieve its objectives largely because it is adopting the legal subsystem's narrower understandings of conflict resolution as well as its patriarchal, simplistic and generalised view of contact as best for children (Smith \& Trinder, 2012). The narrow legal focus on resolving the stalemate, and the mismatch between the one-size-fits-all PIP and these families' complex needs meant that PIP could "make contact happen" but could not "make contact work" in the longer term (ibid, pp. 436-438). Law is sufficiently powerful to enslave mediation discourse, but not to streamline parents' decision-making into the 'good' divorce path. There is, moreover, a group of protracted contact disputes where older children's refusals make direct contact impossible (Harding \& Newnham, 2014, p. 674). It is clear that power is not a simple matter of unidirectional cause and effect. 
In relation to shared residence case law, several judges in the Court of Appeal are now advancing a more pragmatic and child-focused understanding of what SROs can achieve. These communications are now repeated in subsequent judgments, allowing Black LJ to observe in Re E [2011] that the law "has moved on" since Mostyn J advocated using the SRO as standard. ${ }^{42}$ This is due to an emphasis on the fact that in high conflict cases, shared residence can be "a recipe for disaster". ${ }^{43}$ The previous understanding of SROs as having great symbolic value was advanced primarily by two Lords Justices of Appeal who no longer sit in that court, suggesting that while individuals, as closed psychic subsystems, cannot directly steer a social subsystem, they can have an impact on developments. Actors must choose whether and how to communicate when participating in a discourse, but there remains a number of choices. In this way, it can be said that individual judges are not completely powerless. According to Luhmann, this is, indeed, how power works: it limits choices but does not eliminate choice completely (1979, p. 163).

\section{Reform, Again}

However, if the SRO is no longer the legal solution to the political problem of disaffected parenthood, another solution must be found. Dissatisfaction with family law has continued, with allegations of inadequacy and bias being "found primarily in the assertions of disaffected fathers" (Kaganas, 2013, p. 283). This group, as has been discussed above, has become adept at structuring communications in such a way as to maximise impact on the political and legal systems by linking their communications to conservative aspects of those subsystems.

\footnotetext{
42 Re E (Children) [2011] EWCA Civ 1017 per Black LJ at para. 14 citing what she had previously said in T v T [2010] EWCA Civ 1366

$43 \quad$ Re R [2012] EWCA Civ 1326 per Hughes LJ at para.9
} 
Soundbites based on anecdotal evidence and simplistic constructions of equality have also had considerable impact on public opinion, or the general first-order social system that is society. ${ }^{44}$ Thus, in 2014, the UK coalition government amended the Children Act 1989.

Luhmann has commented on how more legislation is increasingly seen within both law and politics as the solution to problems. As Kaganas has noted, the proposed reform makes the government seem like they are doing something to mend "Broken Britain" (2013, p. 290). However, since such "result orientation" will always, to a greater or lesser extent, fail to achieve all of its objectives, these disappointments "are fed back into the system" and more legislation is seen as the solution to correct the unintentional consequences: "legislation incites legislation” (Luhmann 1990, p. 240).

The Children and Families Act 2014 contains a number of changes, two of which relate to shared parenting. The first is the replacement of contact and residence with a new Child Arrangements Order, the aim of which is to remove the incentive for parents to fight over labels. ${ }^{45}$ In Re A R, Mostyn J praised the increased use of SROs since "they avoid the psychological baggage of right, power and control that attends a sole residence order, which was the one of the reasons that we were ridden of the notions of custody and care and control by the [Children] Act of 1989". ${ }^{46}$ The only observation to be made in response to this is that if avoiding psychological baggage did not work after the 1989 Act, why should it work now?

\footnotetext{
44 In a recent Ministry of Justice survey only half of interviewees felt very or fairly confident that the Family Courts listen to both parents and make decisions that are in children's best interests. R Franklyn, 'Analytical Summary: Public attitudes to Civil and Family Court Fees', 2013, Ministry of Justice. https://www.gov.uk/government/uploads/system/uploads/attachment_data/file/262917/public-attitudes-civilfamily-court-fees.pdf (last accessed $11^{\text {th }}$ December 2013).

45 The Children and Families Act 2014, Section 12; Ministry of Justice and Department for Education (2012) The Government Response to the Family Justice Review: A system with children and families at its heart, TSO, p. 69.

46 Re A R (Children) [2010] EWHC 1346 (Fam) per Mostyn J at para.52.
} 
The other change, Section 11, has been more controversial. There are two points to be made about this amendment. Firstly, its title was changed from "Shared Parenting" to "Parental Involvement". This, and other amendments, were made to ensure that the section should not be misunderstood as a presumption in favour of equal sharing. ${ }^{47}$ This is because the Government has taken note of Australian research, which found that law reform with a shared parenting presumption put children at risk of harm where unsuitable fathers insisted upon, and were given, their perceived rights by mothers who felt opposition would be futile. Nevertheless, practitioners and academics have expressed fears that the reform will still be misunderstood this way by parents in England and Wales (Fehlberg, 2012). Autopoietic theory asserts that when a system recreates external information through re-entry, it will tend towards the interpretation that is most compatible with its existing normative and cognitive framework. Although the system is usually unaware of this process and therefore does not perceive itself to be powerful, an observer could see alter's power to frustrate ego's intentions as a counter-flow of power. In relation to abusive parents who see themselves as having more power to insist on their perceived rights this will have real detrimental effects for children who are left with an aggressive or otherwise dangerous parent, and for primary carer parents who feel powerless to intervene.

47 Baroness Butler-Sloss' proposed amendment was accepted by both the House of Lords and the House of Commons on the understanding that it would signal more clearly that this was not about "a right to a certain amount of time with a child": Edward Timpson, Parliamentary Under-Secretary of State for Education, Hansard, HC Deb vol 575 col 636 (10 ${ }^{\text {th }}$ February 2014) [Electronic version]. 
The second point to be made is that the Government has explicitly acknowledged that the reform should not change how courts decide disputes. ${ }^{48}$ Instead, the aim is to send symbolic messages that alter public perceptions that educate both parents and the general public.

A further observation on the patriarchal nature of law (and politics) and these systems' susceptibility to fathers' rights' based turbulence can be made here. The government's stated aims of the 2014 reform were "to restore public confidence in the family justice system by eliminating perceptions of bias, while at the same time keeping parents out of court." (Kaganas, 2013, pp. 282-283). This seems illogical: greater confidence in something usually results in greater use. This logic only makes sense if we assume it to be underpinned by a view of mothers as a group of women who perceive themselves to be powerful, and therefore use the courts to maliciously frustrate fathers' efforts. The aim is perhaps to redistribute power; but since it is based on one, partial and largely erroneous perception of power relationships, it is flawed. ${ }^{49}$

According to the Minister for Children and Families, "The most important element of this is to ensure that there is real confidence in the family justice system." ${ }^{50}$ Kaganas has rightly criticised this emphasis on law's educative power, given "the failure of the law in the past to influence individual parents' behaviour" (Kaganas, 2013, p. 280).

48 Department for Education, Children and Families Bill 2013: Contextual Information and Responses to Pre-Legislative Scrutiny, Cm 8540 (TSO, 2013), at para 63, Annex 1 of Annex B. https://www.education.gov.uk/publications/eOrderingDownload/ Children\%20and\%20Families\%20Bill\%202013.pdf (last accessed 11 August 2013).

49 It is not denied that there are a small number of parents who needlessly frustrate contact; but they are a small minority (Harding \& Newnham, 2014, p. 675). They are also, ironically, the least likely to listen to 'lectures' from law; the costs to the individual autopoietic system of abandoning the self-description of a good, selfless parent that is fighting the case for the child's sake are too high.

50 Edward Timpson's evidence before the Justice Committee: Justice Committee, Fourth Report: Pre-Legislative Scrutiny of the Children and Families Bill (TSO, 2012) para 149. http://www.publications.parliament.uk/pa/cm201213/cmselect/cmjust/739/73907.htm\#a10 (last accessed 11 August 2013). 
Autopoietic theory is helpful in relation to both these points; it explains why the reform is unlikely to improve interparental cooperation but may lead to an increased use of shared residence in families where it does not benefit the children.

Messages are very imperfectly 'translated' (in reality recreated) within the receptor system, what will be rejected or accepted depends on the latter's existing normative and cognitive framework: what the system or person can understand and process and what they want to hear. Parents who already want their equal rights are likely to misunderstand new legislation this way, and if the other parent sees themselves as comparatively powerless, they will allow their choice to be limited to accepting such demands, possibly because they feel resistance is pointless (Fehlberg, 2012). Other parents may choose, for reasons which are perfectly valid to them, to ignore this reform altogether, or to hijack the legal welfare discourse to suit their own ends. Parents may be perceived to have less power, when confronted with the legal system, but they are not powerless, and their role as voters in the political system leads to a suggestion that perhaps power, like communications, flows through circular chains. This examination of the changing law on shared parenting has confirmed Luhmann's observations of power as largely about perceptions of choice, but also as multidimensional and multidirectional (1979, p. 163). 


\section{Bibliography}

Bailey-Harris, Rebecca, Barron, J and Pearce, J (1999) "From Utility to Rights? The Presumption of Contact in Practice", International Journal of Law, Policy and the Family 13: 111-131.

Barnett, Adrienne (2009) 'The Welfare of the Child Re-Visited: In Whose Best Interests? Part II', Family Law: 135-141.

Clarkson, Hugh and Dale Clarkson (2007) "Confusion and Controversy in Parental Alienation”, JSWFL 29: 265-275.

Collier, Richard and Sally Sheldon (2008) Fragmenting Fatherhood: A Socio-Legal Study, Oxford, Hart Publishing.

Department of Health (1991) The Children Act 1989: Guidance and Regulations Vol 1, London, HMSO.

DuBois, Ellen, Mary Dunlap, Carol Gilligan, Catherine MacKinnon, and Carrie MenkelMeadow (1985) "Feminist Discourse, Moral Values and the Law - A Conversation", Buffalo Law Review 34, 11-88

Ekbom, Inger and Åsa Landberg (2007) Innerst Inne var man Rädd, Stockholm, Rädda Barnen \& Socialstyrelsen.

Fehlberg, Belinda (2012) "Legislating for Shared Parenting: How the Family Justice Review got it Right", Family Law: 709-713.

Geldof, Bob (2003) 'The Real Love that Dare Not Speak its Name: A Sometimes Coherent Rant' in Andrew Bainham, Bridget Lindley, Martin Richards and Liz Trinder (eds) Children and their Families: Contact, Rights and Welfare, Oxford, Hart Publishing, 171 200.

Gilmore, Stephen (2006) 'Court Decision-making in Shared Residence Order Cases: A Critical Examination', Child and Family Law Quarterly 18: 478-498.

Gilmore, Stephen (2008) 'The Assumption that Contact is Beneficial: Challenging the "Secure Foundation"', Family Law: 1226-1229.

Harding, Maebh and Annika Newnham, A (2014) 'Initial research findings: the typical levels of parental involvement where post-separation parenting is resolved by court order', Family Law, 672-675.

Harris, Peter and Rob George (2010) 'Parental Responsibility and Shared Residence Orders: Parliamentary Intentions and Judicial Interpretations', Child and Family Law Quarterly 22: 151-171.

James, Adrian, James, Allison and Sally McNamee (2004) 'Turning Down the Volume - Not Hearing Children in Family Proceedings', Child and Family Law Quarterly 16: 189-202. 
Kaganas, Felicity and Shelley Day Sclater (2004) 'Contact Disputes: Narrative Constructions of “Good” Parents', Feminist Legal Studies: 1-27.

Kaganas, Felicity and Christine Piper (2002) 'Shared Parenting - a 70\% Solution?', Child and Family Law Quarterly 14: 365-379.

Kaganas, Felicity (2013) 'A presumption that 'involvement' of both parents is best: deciphering law's messages' Child and Family Law Quarterly: 270-293.

King, Michael \& Christine Piper (1995) How the Law Thinks About Children (2nd Ed), Aldershot, Arena.

Laing, Karen (2006) 'Doing the Right Thing: Cohabiting Parents, Separation and Child Contact', International Journal of Law, Policy and the Family: 169-179.

Law Commission (1988) Family Law Review of Guardianship and Custody, No 172, London, HMSO.

Lawler, Stephanie (1999) 'Children Need but Mothers only Want: the Power of Needs Talk in the Constitution of Childhood', in Julie Seymour and Paul Bagguley (eds) Relating Intimacies: Power and Resistance, Basingstoke, Macmillan Press Ltd, 64-88.

Luhmann , Niklas (1979), Power, Chichester, Wiley.

Luhmann, Niklas (1989) 'Law as a Social System', Northwestern University Law Review 83: 136150.

Luhmann , Niklas (1990) Essays on Self-Reference, Columbia University Press.

Luhmann, Niklas (1992) 'Operational Closure and Structural Coupling: the Differentiation of the Legal System', Cardozo Law Review 13: 1419-1441.

Luhmann, Niklas (1995) 'Legal Argumentation: An Analysis of its Form', Modern Law Review 58: 285-298.

Murray, Charles (1996) "The Emerging British Underclass" in Ruth Lister (Ed) Charles Murray and the Underclass: the Developing Debate, London, Institute of Economic Affairs, 27-53.

Nobles, Richard and David Schiff (2009) 'Why to Judges Talk the Way They Do?' International Journal of Law in Context 5: 25-49.

Philippopoulos-Mihalopoulos, Andreas (2003) "Beauty and the Beast: Art and Law in the Hall of Mirrors", Entertainment Law Review 2: 1- 34.

Reece, Helen (2009) 'The Degradation of Parental Responsibility' in Rebecca Probert, Stephen Gilmore and Johnathan Herring (eds) Responsible Parents and Parental Responsibility, Oxford, Hart Publishing, 85-102.

Rifkin, Janet (1980) “Toward a Theory of Law and Patriarchy”, Harvard Women's Law Journal 3, 83-95. 
Roche, Jeremy (1991) 'The Children Act 1989: Once a Parent Always a Parent', Journal of Social Welfare and Family Law 13: 345-361.

Ryder, Ernest (2008) 'A Tale of Two Thresholds', Family Law: 29-37.

Ryrstedt, Eva (2009) "Samarbetssamtal” Svensk JuristTidning, 821-842.

Silva, Elizabeth and Carol Smart, C (1999) 'Introduction' in E Silva \& C Smart (eds) The New Family?, London, Sage Publications.

Smart, Carol (1995) "Losing the Struggle for Another Voice: the Case of Family Law", Dalhousie Law Journal, 173-195.

Smith, Carole (2004) 'Autopoietic Law and the 'Epistemic Trap': A Case Study of Adoption and Contact', Journal of Law and Society 31: 318-44.

Smith, Leanne and Liz Trinder (2012) 'Mind the Gap: Parent Education Programmes and the Family Justice System', Child and Family Law Quarterly: 428-451.

Spencer, S (2008) 'Benchmarks: Family Residence', Law Society Gazette 39: 24-27.

Teubner, Gunther (1993) Law as an Autopoietic System, London, Blackwell.

Teubner, Gunther (1998) 'Legal Irritants: Good Faith in British law or How Unifying Law Ends up in New Divergences', Modern Law Review 61: 11-32.

Teubner, Gunther (2001) 'Alienating Justice: On the Surplus Value of the Twelfth Camel', in David Nelken and Jin̆ Přbán̆ (eds) Law's New Boundaries: Consequences of Legal Autopoiesis, Aldershot, Ashgate, 21-44.

Teubner, Gunther, David Schiff and Richard Nobles (2003) 'The Autonomy of Law: Introduction to Legal Autopoiesis', in David Schiff and Richard Nobles (eds) Jurisprudence, London, Butterworths, 897-954.

Trinder, Liz, 'Shared Residence: A Review of Recent Research Evidence', Child and Family Law Quarterly 2010: 475-498.

van Krieken, Robert (2005) 'The Best Interests of the Child and Parental Separation: On the Civilizing of Parents', Modern Law Review 68: 25-48.

van Krieken, Robert (2006) 'Law's Autonomy in action: Anthropology and History in Court', Social Ë Legal Studies 15(4), 577-593. 